\title{
The Influence of Inducers on the Coltricia cinnamomea Laccase Activity and its Ability to Degrade POME
}

\author{
Yohanes Bernard Subowo*, Arwan Sugiharto \\ Microbiology Department, Centre Research of Biology, The Indonesian Institute of Sciences, Indonesia \\ *Corresponding Author: subowoyb@gmail.com
}

Submitted: 2021-03-30. Revised: 2021-05-29. Accepted: 2021-08-15

\begin{abstract}
Some species of Basidiomycetes, specifically white rot groups, produce three ligninolytic enzymes, namely, Lignin Peroxidase (LiP), Manganese Peroxidase (MnP) and Laccase (Lac), which have low activity in degrading Palm Oil Mill Effluent (POME). The research objective was to obtain the data on the ability of the Coltricia cinnamomea to produce LiP, MnP, and Lac enzymes to degrade POME. This research also studied the effect of sucrose, alcohol, veratryl alcohol, $\mathrm{CuSO}_{4}$ and $\mathrm{ZnSO}_{4}$, as inducers. Isolates of Coltricia cinnamomea, which were stored in a PDA media at $-20^{\circ} \mathrm{C}$ were obtained from the Microbiology section of the Research Center for Biology (LIPI). Furthermore, the growth media used were DM, Bean sprout Extract (TE) and PDB. The result indicated that PDB is the most suitable growth media for the production of ligninolytic enzymes, because in this medium these enzymes showed the highest activity. It was also observed that sucrose increased the laccase activity by $40.80 \%$. Furthermore, Coltricia cinnamomea was able to reduce the concentration of Poly R-478 by $60.74 \%$, after the addition of $\mathrm{ZnSO}_{4}$. In addition, it degraded and decreased the color and COD of POME, by $72.63 \%$ and $91.19 \%$ respectively, after the addition of veratryl alcohol, and incubation for 10 days. Therefore, this fungus can be used to degrade POME in order to prevent environmental pollution. Coltricia cinnamomea has not been used for POME degradation. By using Coltricia cinnamomea, we obtained new data regarding the activity of laccase and its ability to degrade POME.
\end{abstract}

Key words: POME degradation; inducer; laccase; Coltricia cinnamomea

How to Cite: Subowo, Y. B. \& Sugiharto, A. (2021). The Influence of Inducers on the Coltricia cinnamomea Laccase Activity and its Ability to Degrade POME. Biosaintifika: Journal of Biology \& Biology Education, 13(2), 243-249.

DOI: http://dx.doi.org/10.15294/biosaintifika.v13i2.29660

\section{INTRODUCTION}

The size of oil palm plantations in Indonesia keeps increasing every years. In 2019, the area of oil palm plantations in Indonesia increased by 1.88 percent to 14.60 million hectares. Palm oil (CPO) production increased by $12.92 \%$ to 48.42 million tons (Indonesian Oil Palm Statistics, 2019). However, besides producing palm oil for daily needs, the palm oil industry also produces liquid and solid waste. Palm Oil Mill Effluent (POME) could potentially cause environmental problem due to its characteristics such as dark brown color, thick, dense, and unpleasant odor. The color of POME is predicted to come from melanoidin, biopolymer pigment resulted from Maillard reaction during the processing. Beside melanoidin, phenolic compounds are detected on POME and these compounds are toxic (Zahra et al., 2020).

POME is the residual waste resulting from condensate water after the boiling of palm oil fresh fruit bunches. Untreated POME contains $38.36 \%$ cellulose, $23.21 \%$ hemicellulose, and $26.72 \%$ lignin (Baharuddin et al., 2010). Lignin is a tissue which strengthens plant structures and is recalcitrant (difficult to decompose). Disposal of this waste in water bodies without proper treatment will have an impact on the environment. The production of POME in Indonesia is estimated to be at 28.7 million tons, every years (Irvan et al., 2012).

Basidiomycetes is a group of fungi, which some members secrete ligninolytic enzymes, especially those belonging to the white rot group. According to Gonzalez (2013), most ligninolytic fungi produce at least one laccase isoenzyme. Laccases are blue copper oxidases, found on several plants and secreted by some ligninolytic fungi. The enzyme oxidizes some organic compounds, especially phenolic and aromatic amines (Zucca et al., 2015). Laccase degrades phenolics and non-phenolics compounds and also some pollutants in the environment (Upadhyay et al., 2016). Laccase naturally play important roles in catalyzing lignification, delignification, plants'stress management, as well as fungal morphogenesis and virulence (Sitarz et al., 2016).

Some species of white rot fungi secrete poorly active laccase. Thus, various efforts has been done to increase laccase production by inducting laccase gene expression on white rot fungi. Several materials such as aromatic compounds related to lignin and their derivatives, carbon and nitrogen sources, and metal ions regulate the transcription of the laccase gene (Piscitelli et al., 2011). Higher enzyme activities 
result in a greater and faster reaction in substrates, and increase the application and efficiency of the enzyme's catalysis process (Rao et al., 2014). In Pleurotus sajor-caju strain PS-2001 culture on media with sucrose and added with aromatic syringaldazine, benzoic acid, galic acid, vanillin, and $\mathrm{CuSO}_{4}$ increased laccase activity up to $58-80 \mathrm{U} / \mathrm{mL}$ (Bettin et al., 2014).

The use of Coltricia cinnamomea (Tiger's Eye Fungus) to degrade POME has never been done. Similarly the addition of inducers such as veratryl alcohol, $\mathrm{ZnSO}_{4}$, and alcohol to increase laccase activity, for faster degradation process has never been heard of, therefore, this research was conducted. The objective of this study was to obtain valuable data on the ability of the Coltricia cinnamomea to degrade POME, and the effect of adding a number of inducers on its laccase activity. We obtained new data regarding the activity of laccase and its ability to degrade POME by used Coltricia cinnamomea. It added new insight into the utilization of fungi for POME degradation.

\section{METHODS}

Microorganism. Isolates of Coltricia cinnamomea, which were stored in a PDA media, at $20^{\circ} \mathrm{C}$, were obtained from the Microbiology section of the Research Center for Biology (LIPI). Furthermore, the inducers used include: veratryl alcohol, alcohol, $\mathrm{ZnSO}_{4}$, sucrose, $\mathrm{CuSO}_{4}$, while the media used were DM (Defined Medium), TE (Taoge Extract/Bean sprout Extract), PDB (Potato Dextrose Broth) and Poly R-478 media.

Media. DM was composed of: $10 \mathrm{~g}$ glucose, $1 \mathrm{~g}$ $\mathrm{NH}_{4} \mathrm{NO}_{3}, 0.8$ g $\mathrm{KH}_{2} \mathrm{PO}_{4}, 0.2 \mathrm{~g} \mathrm{Na}_{2} \mathrm{HPO}_{4}, 0.5 \mathrm{~g}$ $\mathrm{MgSO}_{4} .7 \mathrm{H}_{2} \mathrm{O}, 2 \mathrm{~g}$ of yeast extract (Songulashvili et al., 2007), while Bean Sprout Extract (TE) was composed of $100 \mathrm{~g}$ bean sprout, and $60 \mathrm{~g}$ sucrose. Furthermore, the compositions of PDB were $4.0 \mathrm{~g}$ Potato starch and $20.0 \mathrm{~g}$ Dextrose, while that of Poly R-478 were: 0.60 g KH $_{2} \mathrm{PO}_{4}, 0.50 \mathrm{~g} \mathrm{MgSO}_{4} .7 \mathrm{H}_{2} \mathrm{O}$, $0.40 \mathrm{~g} \mathrm{KH}_{2} \mathrm{PO}_{4}, 0.22 \mathrm{~g}\left(\mathrm{NH}_{4}\right) 2$ tartrate, $40.0 \mathrm{~g}$ sorbose, 0.20 g Poly R-478 (Sigma), and $10.0 \mathrm{~mL}$ mineral solution stock plus distilled water, up to $1 \mathrm{~L}$ (Glend and Gold, 1983). In addition, mineral solution stock composed of: $7.4 \mathrm{~g} \mathrm{CaCl}_{2} \cdot 2 \mathrm{H}_{2} \mathrm{O} 1.2 \mathrm{~g}$ Ferri citrate, $0.7 \mathrm{~g} \mathrm{ZnSO}_{4} .7 \mathrm{H}_{2} \mathrm{O}, 0.5 \mathrm{~g} \mathrm{MnSO}_{4} \cdot 4 \mathrm{H}_{2} \mathrm{O}, 0.1 \mathrm{~g}$ $\mathrm{CoCl}_{2} .6 \mathrm{H} 2 \mathrm{O}$, and $10.0 \mathrm{mg}$ Thiamin $\mathrm{HCl}$, added with distilled water up to $1 \mathrm{~L}$.

\section{Ligninolytic activity of fungus}

Laccase (Lac) activity was calculated using the method of Papinutti et al. (2003). The test is based on the oxidation of ABTS by the enzyme laccase. The reaction mixture contained $0.5 \mathrm{~mL}$ of citrate buffer at
$\mathrm{pH} 6.0,0.1 \mathrm{~mL}$ of $1 \mathrm{mM}$ ABTS and $0.4 \mathrm{~mL}$ of the enzyme supernatant. The tube was then shaken slowly to mix all ingredients and allowed to stand for 15 minutes at room temperature. The absorbance was measured at a wavelength of $420 \mathrm{~nm}$.

Manganese Peroxidase (MnP) activity was determined using the method of Yoshida et al. (1996). $\mathrm{MnP}$ was measured by monitoring the oxidation of guaiacol spectrophotometrically. The reaction mixture contained $0.1 \mathrm{~mL}$ guaiacol $4 \mathrm{mM}, 0.1 \mathrm{~mL}$ lactate buffer $50 \mathrm{M}$ at $\mathrm{pH} 4.5,0.2 \mathrm{~mL} \mathrm{MnSO} 41 \mathrm{mM}$, $0.3 \mathrm{~mL}$ distilled water, $0.1 \mathrm{~mL} \mathrm{H} 2 \mathrm{O} 2$, and $0.2 \mathrm{~mL}$ of enzyme solution. Guaiacol oxidation was then monitored by watching for any rise in absorbance at $465 \mathrm{~nm}$.

Lignin Peroxidase (LiP) activity was estimated using the Tien and Kirk method (1983). Furthermore, the assay was based on the oxidation of veratryl alcohol to veratryl aldehyde, in the presence of $\mathrm{H}_{2} \mathrm{O}_{2}$. The reaction mixture contained $0.1 \mathrm{~mL}$ of $8 \mathrm{mM}$ veratryl alcohol, $0.2 \mathrm{~mL}$ acetate buffer $50 \mathrm{mM}$ of $\mathrm{pH}$ 3, $0.45 \mathrm{~mL}$ distilled water, $0.05 \mathrm{H}_{2} \mathrm{O}_{2} 5 \mathrm{mM}$, and 0.2 $\mathrm{mL}$ enzyme solution. The increasing of absorbance was monitored at $310 \mathrm{~nm}$.

\section{Fungus ability to degrade Poly R-478}

To test the ability of fungus to degrade Poly R$478,5 \mathrm{~mL}$ of mycelium suspension was inoculated into $45 \mathrm{~mL}$ of Poly R-478 media. The mixture was then incubated on a shaker at a speed of $115 \mathrm{rpm}$, at room temperature. The R-478 poly content was measured after incubation for 7 days, using a spectrophotometer. The absorbance was read at a wavelength of $520 \mathrm{~nm}$ (Moreira et al., 2004).

\section{The ability of fungi in POME degradation}

This study used Coltricia cinnamomea in order to remediate the immense concentration of colorant in palm oil mill effluent (POME). Furthermore, the inducers, $\mathrm{CuSO}_{4}$, sucrose, veratryl alcohol, alcohol and $\mathrm{ZnSO}_{4}$ were also added to boost the laccase activity. In total, six different media treatments were prepared including the untreated POME for $100 \mathrm{~mL}$ (1), which were POME with the addition of $\mathrm{CuSO}_{4}$ $200 \mu \mathrm{M}(2), 15 \mathrm{~g} / \mathrm{L}$ sucrose (3), $40 \mathrm{mM}$ veratryl alcohol (4), $40 \mathrm{~g} / \mathrm{L}$ alcohol (5), and $100 \mu \mathrm{M} \mathrm{ZnSO}_{4}$ (6). All media were then inoculated with $10 \mathrm{~mL}$ of Coltricia cinnamomea mycelium suspension and incubated and shook (115 rpm) at room temperature for 10 days. After incubation, mycelium and supernatant were separated by centrifugation $(9000$ $\mathrm{rpm}$ ) and the supernatant layer was collected. POME decolorization was then measured by Spectrophotometer at a wavelength of $600 \mathrm{~nm}$. 


\section{COD degradation}

COD levels in POME were measured using the method of Xia et al. (2009). Observations were made using a spectrophotometer by reading the absorbance reduction on 0 to day 10, at a wavelength of $600 \mathrm{~nm}$

\section{Data analysis}

At a level of $p<0.05$. The values were expressed as the mean $\pm \mathrm{SD}$.

\section{RESULT AND DISCUSSION}

Coltricia cinnamomea belongs to the family of Polyporaceae. Furthermore, it secreted all three ligninolytic enzymes, namely, Laccase (Lac), Manganese Peroxidase (MnP) and Lignin Peroxidase (LiP), in the three media. However, the activity of each enzyme was different from one media to another. The highest amount of Lac and MnP were obtained in PDB media, with concentrations of 245.36 and 1735.53 units $/ \mathrm{mL}$ respectively, while LiP was found in DM media with a concentration of 1415.76 units/mL (Table 1).

Table 1. Ligninolytic activity of Coltricia cinnamomea on several growth media

\begin{tabular}{|c|c|c|c|}
\hline Media & $\begin{array}{c}\text { Lac } \\
\text { Activity } \\
\text { (unit/mL) }\end{array}$ & $\begin{array}{l}\text { MnP Activity } \\
\text { (unit/mL) }\end{array}$ & $\begin{array}{l}\text { LiP Activity } \\
\text { (unit/mL) }\end{array}$ \\
\hline $\mathrm{DM}$ & $\begin{array}{c}108.79 \pm \\
5.30\end{array}$ & $1584.02 \pm 101.91$ & $1415.76 \pm 108.63$ \\
\hline TE & $\begin{array}{c}189.81 \pm \\
7.22\end{array}$ & $1480.71 \pm 83.50$ & $913.97 \pm 80.64$ \\
\hline PDB & $\begin{array}{c}245.36 \pm \\
34.25\end{array}$ & $1735.53 \pm 20.66$ & $1218.63 \pm 121.21$ \\
\hline
\end{tabular}

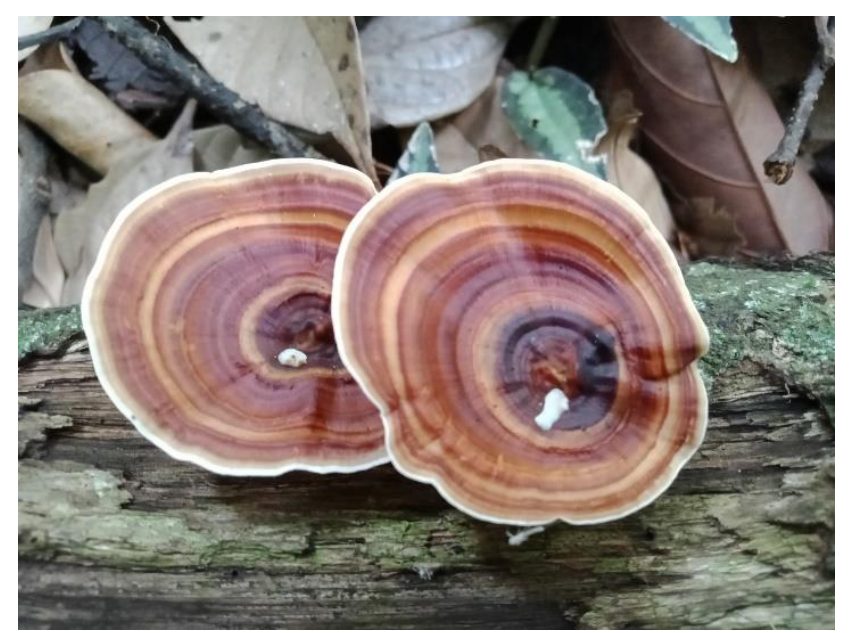

Figure 1. Coltricia cinnamomea

(Photo:Arwan/Subowo)

PDB (Potato Dextrose Broth) was considered the most suitable for the production of Laccase and Manganese peroxidase enzymes because both enzymes showed the highest activity compared to the other media, while the highest LiP activity was on DM media. This is consistent with a research conducted by Subowo. In that study, Coprinus cinereus was inoculated in DM, PDB and TE, and the result obtained showed that the highest enzyme activity of Lac, LiP, and MnP occurred in the PDB media (Subowo, 2017). Potato extract in PDB contains carbohydrates which affect fungal growth and enzymes production. Correspondingly, research by Taurisia that inoculated Alternaria alternata (Fries) Keissler on seven types of media: Potato Dextrose Agar (PDA), Potato Carrot Agar (PCA), Sabouraud Dextrose Agar (SDA), Czapek Dox Agar (CDA), Corn Meal Agar (CMA), Nutrient Agar (NA), and Malt Extract Agar (MEA), showed that Alternaria alternata grew well on PDA (20g), PCA $(20 \mathrm{~g})$, and SDA $(40 \mathrm{~g})$ media. It was due to the high content of dextrose and carbohydrates in the 3 media which play an important role in the metabolic process of the fungi (Taurisia et al., 2015).

In this study, inducers were added, to increase the activity of laccase produced by Coltricia cinnamomea in the PDB media. Inducers added: including $\mathrm{CuSO}_{4}$, sucrose, alcohol, $\mathrm{ZnSO}_{4}$, and veratryl alcohol. The result showed that inducers increased the fungal laccase activity. However, the highest increase occurred in media inoculated with sucrose (40.8\%), because it is a source of carbon $(\mathrm{C})$, followed by $\mathrm{CuSO}_{4}$, and finally alcohol (13.48\%) (Table 2).

Table 2. The activity of laccase produced by Coltricia cinnamomea on PDB after the addition of various inducers

\begin{tabular}{ccc}
\hline Inducer & $\begin{array}{c}\text { Laccase Activity } \\
(\mathrm{U} / \mathrm{mL})\end{array}$ & $\begin{array}{c}\text { Increase } \\
(\%)\end{array}$ \\
\hline Control & $138.18 \pm 11.94$ & - \\
Alcohol & $159.72 \pm 38.48$ & 13.48 \\
Veratryl & $163.76 \pm 26.18$ & 15.62 \\
alcohol & $165.62 \pm 3.47$ & 16.56 \\
$\mathrm{ZnSO}_{4}$ & $185.99 \pm 30.75$ & 25.70 \\
$\mathrm{CuSO}_{4}$ & $233.44 \pm 74.77$ & 40.80 \\
Sucrose & & \\
\hline
\end{tabular}

According to Dana glucose, maltose, sucrose, fructose, glycerol, and lactose are common carbon sources. Sucrose in the media is hydrolyzed by the fungus into fructose and glucose. Fructose impacts laccase activity (Dana et al., 2017). Hu reported that fructose produced by Gongronella sp. w5 was more readily available to be used by Coprinopsis cinerea as carbon sources contributing to the growth and laccase secretion up to $110.6 \pm 3.3 \mathrm{U} / \mathrm{L}$ (Hu et al., 2019). Dhakar and Pandey (2013) showed similar results that fructose and ammonium sulfate that are suitable carbon and nitrogen sources to increase the laccase production by Trametes hirsuta (MTCC 11397). 
Similarly, glucose influences laccase activity. Schneider investigated suitable $\mathrm{C}$ and $\mathrm{N}$ sources and concentration to support laccase, peroxidase, and manganese peroxidase activity by Marasmiellus palmivorus VE111. Combination of glucose and casein resulted in the highest laccase activity (5134 $\mathrm{U} / \mathrm{mL})$, total peroxidase $(187 \mathrm{U} / \mathrm{mL})$ and manganese peroxidase $(57 \mathrm{U} / \mathrm{mL})$ (Schneider et al., 2018).

The addition of inducers to poly $\mathrm{R}$, which is a polymeric dye, improved the decolorization effect of ligninolytic enzyme. The highest increase (up to $60.74 \%)$ occurred with the addition of $\mathrm{ZnSO}_{4}(27.79$ ppm), followed by veratryl alcohol (22.44 ppm), while the lowest (17.30\%) occurred with the addition of alcohol (7.92 ppm) (Table 3).

Table 3. The decrease of Poly R-478 concentration by Coltricia cinnamomea enzymes

\begin{tabular}{|c|c|c|c|}
\hline Inducer & Absorbance & $\begin{array}{c}\text { Decrease } \\
(\%)\end{array}$ & $\begin{array}{c}\text { Poly R-478 } \\
\text { concentration } \\
\text { decrease (ppm) }\end{array}$ \\
\hline $\begin{array}{l}\text { Poly R + } \\
\text { Fungi }\end{array}$ & 0.0991 & 5.79 & 2.66 \\
\hline $\begin{array}{l}\text { Poly R + } \\
\text { Fungi + } \\
\text { Alcohol }\end{array}$ & 0.0870 & 17.30 & 7.92 \\
\hline $\begin{array}{l}\text { Poly R + } \\
\text { Fungi + } \\
\text { Sucrose }\end{array}$ & 0.0768 & 26.99 & 12.35 \\
\hline $\begin{array}{l}\text { Poly R + } \\
\text { Fungi + } \\
\mathrm{CuSO}_{4} \\
\text { Poly R + }\end{array}$ & 0.0648 & 38.40 & 17.57 \\
\hline $\begin{array}{l}\text { Fungi + } \\
\text { Ver. } \\
\text { alcohol }\end{array}$ & 0.0536 & 49.04 & 22.44 \\
\hline $\begin{array}{l}\text { Poly R + } \\
\text { Fungi + } \\
\mathrm{ZnSO}_{4}\end{array}$ & 0.0413 & 60.74 & 27.79 \\
\hline
\end{tabular}

The addition of $\mathrm{ZnSO}_{4}$ to the Poly R-478 media increased Coltricia cinnamomea laccase activity. Therefore, the concentration of poly $\mathrm{R}$ showed the greatest decrease compared to that of the control, which was $60.74 \%$, after incubation for 10 days. Furthermore, the addition of low concentration metal ions to the media, increased the activity of laccase and consequently caused the faster degradation of Poly R-478. Yang reported that $\mathrm{MnSO}_{4}, \mathrm{CoCl}_{2}$, $\mathrm{FeSO}_{4}, \mathrm{NaMoO}_{4}$, and $\mathrm{H}_{3} \mathrm{BO}_{3}$ showed no effects on laccase production by Cerrena sp. HYB07, while $\mathrm{Cu}^{2+}$ and $\mathrm{Zn}^{2+}$ induced laccase production. When $\mathrm{Cu}^{++}$or $\mathrm{Zn}^{++}$ions were not added to the fermentation media, laccase activity showed a decrease as much as 99.95 and $31.78 \%$ (Yang et al., 2016). The activity of $\mathrm{LiP}$ and $\mathrm{MnP}$ increased on Phanerochaete chrysosporium culture when $\mathrm{Zn}^{++}$and $\mathrm{Cu}^{++}$at low concentrations were added to metal-free culture media (Asgher, 2011). The presence of $\mathrm{FeSO}_{4}$ and $\mathrm{ZnSO}_{4}$ as trace elements in the media increased the maximum production of laccase on Bacillus sp. PK4 isolate (Rajeswari \& Bhuvaneswari, 2016).

The enzymes produced by Coltricia cinnamomea decolorized POME by $13.96 \%$ after incubation for 10 days. Moreover, the addition of inducers increased POME decolorization became 37.79-72.63\%. The most significant increase $(72.63 \%)$ occurred with the addition of veratryl alcohol (Table 4).

Table 4. POME degradation by Coltricia cinnamomea after inducers addition

\begin{tabular}{lc}
\hline \multicolumn{1}{c}{ Treatments } & $\begin{array}{c}\text { POME decolorization } \\
(\%)\end{array}$ \\
\hline POME + Fungi & $13.96 \pm 0.91^{\mathrm{a}}$ \\
POME + Fungi + sucrose & $37.79 \pm 0.82^{\mathrm{b}}$ \\
POME + Fungi + alcohol & $46.88 \pm 4.97^{\mathrm{c}}$ \\
POME + Fungi + $\mathrm{CuSO}_{4}$ & $47.88 \pm 7.65^{\mathrm{c}}$ \\
POME + Fungi + $\mathrm{ZnSO}_{4}$ & $54.68 \pm 5.23^{\mathrm{c}}$ \\
POME + Fungi + veratryl & $72.63 \pm 3.96^{\mathrm{d}}$ \\
alcohol & \\
\hline
\end{tabular}

Several aromatic compounds have been used to increase laccase production including veratryl alcohol, guaiacol, ferulic acid and 1hydroxybenzotriazole (Kocyigit et al., 2012). Saraiva reported that laccase production by Trametes versicolor increased by two, four, and eight-fold due to the presence of ligninosulphonates, veratryl alcohol, and xylidine inducer, respectively (Saraiva et al., 2012). Usha reported that $0.02 \%$ veratryl alcohol added to Stereum ostrea culture increased the production of 3 enzymes. Laccase activity increased 1.9 times compared to control and $\mathrm{MnP}$ and $\mathrm{LiP}$ production increased by $50 \%$ (Usha et al., 2014). The POME color reduction of $72.63 \%$ after incubation for 10 days was the highest result of degradation by laccase produced by $C$. cinnamomea. Neoh reported that Curvularia clavata reduced the color of POME by $80 \%$ with $54 \%$ as a result of biosorption and $46 \%$ as a result of degradation after 5 days of treatment (Neoh et al., 2013).

COD decreased from $12512 \mathrm{mg} / \mathrm{L}$ (fresh POME) to $5510 \mathrm{mg} / \mathrm{L}$ with Coltricia cinnamomea treatment without an inducer, in the POME degradation process. The addition of inducer accelerated the reduction of COD, alcohol (1203 mg/L), $\mathrm{ZnSO}_{4}$ $(1191 \mathrm{mg} / \mathrm{L}), \mathrm{CuSO}_{4}(1140 \mathrm{mg} / \mathrm{L})$, sucrose 1127 $\mathrm{mg} / \mathrm{L}$, and veratryl alcohol $(1102 \mathrm{mg} / \mathrm{L})$. The greatest decrease $(91.19 \%)$ occurred after the addition of veratryl alcohol, while the lowest occurred in the control, where no inducer was added (Figure 2). 


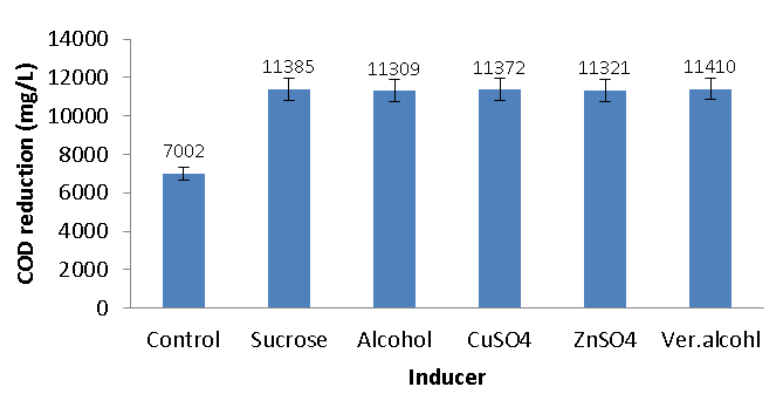

Figure 2. The decrease of COD level of POME by Coltricia cinnamomea after the addition of inducers

Ligninolytic enzyme produced by the Coltricia cinnamomea fungus is proven to reduce COD levels in POME. Furthermore, untreated POME had a relatively high COD level. The addition of inducers to POME caused an increase in enzyme activities, which led to faster degradation process. However, all the inducers tested did not cause a significant alteration on COD level. According to Soleimaninanadegani and Manshad, POME contains high organic matter, COD concentrations ranged from 45,000-65,000 $\mathrm{mg} / \mathrm{L}$ and BOD of 18,000$48,000 \mathrm{mg} / \mathrm{L}$ (Soleimaninanadegani \& Manshad, 2014). Furthermore, Coltricia cinnamomea reduced COD levels by $91.19 \%$ after the addition of veratryl alcohol. This result is still higher than that of Marasmius pulcheripes $\mathrm{J} 8$, which was able to reduce COD level by $81 \%$ after incubation for 20 days (Subowo \& Sugiharto, 2019). Lanka and Pydipalli reported that Emericella nidulans NFCCI 3643 revealed to be an excellent biological agent in degrading organic matters in POME. This fungus reduced COD by $80.28 \%$, BOD by $88.23 \%$, and fat content by $87.34 \%$ (Lanka \& Pydipalli, 2018). Bala reported that POME can be degraded by a mixture of indigenous POME microbes consisting of Micrococcus luteus 101PB, Stenotrophomonas maltophilia 102PB, Bacillus cereus103PB, Providencia vermicola 104PB, Klebsiella pneumonia 105PB, Bacillus subtilis 106PB, Aspergillus fumigatus 107PF, Aspergillus nomius 108PF, Aspergillus niger 109PF, and Meyerozyma guilliermondii 110PF. These microbes decreased BOD level as much as $90.23 \%$, COD level up to 91.06\% and TSS as much as $92.23 \%$ (Bala et al., 2018).

Coltricia cinnamomea is a member of the Basidiomycetes group. There has not been research that explains the ability of Coltricia cinnamomea to produce the ligninolytic enzymes. Therefore, this research will obtain new information about this fungus and the possibility of POME degradation. This new information can be used to treat palm oil industry waste, especially POME and add new knowledge about this fungus.

\section{CONCLUSION}

Coltricia cinnamomea produced three ligninolytic enzymes (Laccase, Manganese Peroxidase, Lignin Peroxidase) on PDB medium. This fungus can reduce the color of POME by $13.96 \%$ after incubation for 10 days. The addition of veratryl alcohol increased the POME color reduction by $72.63 \%$. This fungus also reduced COD at POME by $91.19 \%$ after adding veratryl alcohol.

\section{ACKNOWLEDGEMENTS}

The author acknowledges with gratitude for the support and chance given by the Head of Research Centre for Biology- The Indonesian Institute of Sciences (LIPI).

\section{REFERENCES}

Asgher, M. (2011). Characterization of a novel manganese peroxidase purified from solid state culture of Trametes versicolor IBL-04. Bioresources 6, 4317-4330.

Bala, J.D., Lalung, J., Al-Gheethi, A.A.S., Kaizar, H. \& Ismail, N. (2018). Reduction of Organic Load and Biodegradation of Palm Oil Mill Effluent by Aerobic Indigenous Mixed Microbial Consortium Isolated from Palm Oil Mill Effluent (POME). Water Conserv Sci Eng, 18 pp. https://doi.org/10.1007/s41101-018-0043-9.

Bettin, F., Montanari, Q., Calloni, R., Gaio, T.A., Silveira, M.M., \& Dillon, A.J.P. (2014). Additive effect of $\mathrm{CuSO} 4$ and aromatic compounds on laccase production by Pleurotus sajor-caju PS2001 using sucrose as a Carbon source. Brazilian Journal of Chemical Engineering, 31(2), 335-346.

Baharuddin, A.S., Hock, L.S., Yusof, M.Z., \& Rahman, N.A.A. (2010). Effects of palm oil mill effluent (POME) anaerobic sludge from $500 \mathrm{~m} 3$ of closed anaerobic methane digested tank on pressed-shredded empty fruit bunch (EFB) composting process. African Journal of Biotechnology 9 (16), 2427-2436.

Dana, M., Khaniki, G.B., Mokhtarieh, A.A., Davarpanah, S.J. (2017). Biotechnological and Industrial Applications of Laccase: A Review. Journal of Applied Biotechnology Reports, 4 (4), 675-679.

Dhakar, K., \& Pandey, A. (2013). Laccase Production from a Temperature and $\mathrm{pH}$ Tolerant Fungal Strain of Trametes hirsuta (MTCC 11397). Hindawi Publishing Corporation Enzyme Research, 9 pp.

Glenn, J. K., \& Gold, M. H. (1983). Decolorization of several polymeric dyes by the lignin-degrading 
Basidiomycetes Phanerochaete chrysosporium. Appl. Environ Microbiol. 45(6), 1741-1747

Gonzalez, J.C., Medina, S.C., Rodriguez, A., Osma, J.F., \& Almeciga-Diaz, C.J. (2013). Production of Trametes pubescens laccase under submerged and semi-solid culture conditions on agroindustrial wastes. PLOS ONE. 8 (9), 1-14.

Hu, J., Zhang, Y., Xu, Y., Sun, Q., Liu, J., Fang, W., Xiao, Y., Kues, U., \& Fang, Z. (2019). Gongronella sp. w5 elevates Coprinopsis cinerea laccase production by carbon source syntrophism and secondary metabolite induction. Appl Microbiol Biotechnol. 103, 411-425.

Irvan, Trisakti, B., Vincent, M., \& Tandean, Y. (2012). Further processing of palm oil liquid waste used effective microorganism aerobically in order to reduce of TSS value. Jurnal Teknik Kimia USU 1 (2), 27-30.

Kocyigit, A., Yasa, I., Pazarbasi, M.B., \& Ozdemir, G. (2012). Production of laccase from Trametes trogii TEM H2: a newly isolated white rot fungus by air sampling. Journal of Basic Microbiology $52,1-9$.

Kuo, M. (2010). Coltricia cinnamomea. Retrieved from the Mushroom Expert.Com Web site: $\mathrm{http} / / / \mathrm{www}$.mushroomexpert.com/coltricia_cinna momea.html

Lanka, S., \& Pydipalli, M. (2018). Reduction of organic load from palm oil mill effluent (POME) using selected fungal strains isolated from POME dump sites. African Journal of Biotechnology, 17 (36), 1138-1145.

Moreira, M.T., Viacava, C., \& Vidal, G. (2004). Fedbatchdecolorization of poly R-478 by Trametes versicolor. Brazilian Archives of Biology and Technology 47(2),179-183.

Neoh, C.H., Lam, C.Y., Lim, C.K., Yahya, A., Ibrahim, Z. (2013). Decolorization of palm oil mill effluent using growing cultures of Curvularia clavata. Environ Sci Pollut Res, 12 pp.

Papinutti, V.L., Diorio, L.A., \& Forchiassin, F. (2003). Production of laccase and manganese peroxidase by Fomes sclerodermeus grown on wheat bran. J. Ind. Microbiol. Biotechnol. 30, 157160.

Piscitelli, A., Giardina, P., Lettera, V., Pezzella, C., Sannia, G., \& Faraco, V. (2011).

Induction and Transcriptional Regulation of Laccases in Fungi. Current Genomics, 12, 104112.

Rajeswari, M., \& Bhuvaneswari, V. (2016). Production of extracellular laccase from the newly isolated Bacillus sp. PK4. African Journal of Biotechnology, 15 (34), 1813-1826.

Rao, M.A., Scelza, R., Acevedo, F., Diez, M.C., Gianfreda, L. (2014). Enzymes as useful tools for environmental purposes. Chemosphere, 107, 145162.

Saraiva, J.A., Tavares, A.P.M., Xavier, A.M.R.B. (2012). Effect of the Inducers Veratryl Alcohol, Xylidine, and Ligninosulphonates on Activity and Thermal Stability and Inactivation Kinetics of Laccase from Trametes versicolor. Appl Biochem Biotechnol. 167, 685-693.

Schneider, W.D.H., Fontana, R.C., Mendonca, S., de Siqueira, F.G., Dillon, A.J.P., Camassola, M. (2018). High level production of laccases and peroxidases from the newly isolated white-rot basidiomycete Marasmiellus palmivorus VE111 in a stirred-tank bioreactor in response to different carbon and nitrogen sources. Process Biochemistry, 69, 1-11.

Sitarz, A.K., Mikkelsen, J.D., \& Meyer, A.S. (2016). Structure, functionality and tuning up of laccases for lignocellulose and other industrial applications. Critical Reviews in Biotechnology, 36(1), 70-86.

Songulashvili, G., Elishasvili, V., Wasser, S.P., Nevo, E., Hadar, Y. (2007). Basidiomycetes laccase and manganese peroxidase activity in submerged fermentation of food industry wastes. Enzyme and Microbial Technology 41, 57-61.

Soleimaninanadegani, M., \& Manshad, S. (2014). Enhancement of Biodegradation of Palm Oil Mill Effluents by Local Isolated Microorganisms. Hindawi Publishing Corporation International Scholarly Research Notices, 8 pp.

Subowo, Y.B. (2017). The utilization of ink cap mushroom (Coprinus cinereus) on palm oil mill effluent degradation. Journal of Biological Researches 22 (21), 61-65.

Subowo, Y.B., \& Sugiharto, A. (2019). The Interaction between Marasmius pulcheripes J8 and Soil Fungi on Laccase Activity for POME Degradation. Biosaintifika 11 (3): 178-184.

Taurisia, P.P., Proborini, M.W., Nurhantoro, I. (2015). The effect of media on the growth and biomass of fungi Alternaria alternata (Fries) Keissler. Jurnal Biologi 19 (1),30-33.

Tien, M. \& Kirk, T.K. (1983). Lignin-Degrading Enzyme from the Hymenomycete Phanerochaete chrysosporium Burds. Science. 221 (4611), 661663.

Upadhyay, P., Shrivastava, R.R., Agrawal, P.K. (2016). Bioprospecting and biotechnological applications of fungal laccase. Biotech, 6(15), 12 pp.

Usha, K.Y., Praveen, K., \& Reddy, B.R. (2014). Enhanced Production of Ligninolytic Enzymes by a Mushroom Stereum ostrea. Hindawi Publishing Corporation Biotechnology Research International, $9 \mathrm{pp}$. 
Xia, C. Y., Zuo, J.L., Lu, J., Li, J., Chen, L. Z., Li, S.H., Tao, T., Li, T., Li, X., Wang, Y. L., Liu, Y. (2009). A spectrophotometric method for determination of chemical oxygen demand using home- made reagents. Desalination 239, 139-145.

Yang, J., Wang, G., Ng, T.B., Lin, J., \&Ye, X. (2016). Laccase Production and Differential Transcription of Laccase Genes in Cerrena sp. in Response to Metal Ions, Aromatic Compounds, and Nutrients. Frontiers in Microbiology, 6, 1-11.

Yoshida, S., Yonehara, S,. Minami, S., Ha, H., Iwahara, K., Watanabe, T., Honda, Y., \& Kuwahara, M. (1996). Production and characterization of ligninolytic enzymes of Bjerkandera adusta grown on wood meal/wheat bran culture and production of these enzymes using a rotary-solid fermenter. Mycoscience 37 (4), 417-425.

Zahra, H., Kurniawan, I., Hakim, A. (2020). The Efficiency of Melanoidin Based-Waste Degradation with Different Biological Methods. Curr. Biochem. 7(2), 52-60.

Zucca, P., Cocco, G., Sollai, F., Sanjust, E. (2015). Fungal laccases as tools for biodegradation of industrial dyes. Biocatalysis 1, 82-108. 